\title{
PENGGUNAAN ALIH KODE DAN CAMPUR KODE DALAM INTERAKSI MASYARAKAT DI KECAMATAN CABANGBUNGIN KABUPATEN BEKASI
}

\author{
Eva Muzdalifah ${ }^{1}$ \\ Universitas Singaperbangsa Karawang \\ evamuzdalifah06028@gmail.com \\ Sinta Rosalina ${ }^{2}$ \\ Universitas Singaperbangsa Karawang \\ sinta@fkip.unsika.ac.id
}

\begin{abstract}
ABSTRAK
Penelitian ini bertujuan untuk mengetahui penggunaan alih kode dan campur kode dalam interaksi masyarakat di Kecamatan Cabangbungin, Kabupaten Bekasi. Penelitian ini menggunakan pendekatan kualitatif. Subjek penelitian ini adalah beberapa masyarakat Kecamatan Cabangbungin, di sini peneliti memakai 3 narasumber yaitu: Anisah (18) dari Desa Jayalaksana, Umi (17) dari Desa Setialaksana, dan Nela (18) dari Desa Sindangsari. Mereka bertiga adalah masyarakat Cabangbungin dari 3 desa berbeda. Penelitian ini peneliti mengambil objek dari tindak tutur masyarakat Kecamatan Cabangbungin. Penelitian ini memakai teknik pengumpulan data melalui terjun langsung ke lapangan atau observasi. Peneliti mencoba berinteraksi dengan berbagai sumber yang menggunakan bahasa Jawa Indramayu untuk diteliti dalam penggunaan alih kode dan campur kode dengan bahasa Indonesia. Peneliti memakai teknik cakap, rekam, dan catat. Teknik analisis data dalam penelitian ini dengan cara klasifikasi data, dan analisis data. Pada penelitian ini peneliti menemukan 10 wujud alih kode dan campur kode. Terdapat 4 wujud alih kode yang semuanya alih kode internal dan 6 wujud campur kode, dengan 2 campur kode internal dan 4 campur kode eksternal.
\end{abstract}

Kata Kunci: Alih Kode, Campur Kode, Interaksi

\section{A. PENDAHULUAN}

Manusia dapat berinteraksi satu sama lain melalui komunikasi yang berbentuk bahasa. Secara umum bahasa yang natural atau alami adalah bahasa atau interaksi dalam bentuk lisan atau percakapan, karena di dalamnya terdapat maksud atau pesan yang ingin disampaikan secara spontan dan tanpa proses edit. Oleh karena itu, bahasa memiliki peran penting di masyarakat dalam berkomunikasi. Bahasa pada hakikatnya bersifat arbitrer, yang merupakan sistem lambang bunyi untuk berkomunikasi. Proses komunikasi dalam masyarakat tidak hanya berlangsung dalam satu bahasa saja, tetapi bisa lebih dari satu bahasa. Berbagai interaksi yang terjadi antar individu dalam kelompok maupun kelompok lain menyebabkan terjadinya kontak bahasa sehingga muncul kedwibahasaan dan kemultibahasaaan dalam masyarakat. Kontak yang intensif antara dua bahasa atau lebih di dalam situasi bilingual atau 


\section{Lingua Rima: Jurnal Pendidikan Bahasa dan Sastra Indonesia \\ Vol. 10 No. 3 September 2021 \\ http://jurnal.umt.ac.id/index.php/lgrm}

multilingual cenderung mengakibatkan timbulnya gejala alih kode dan campur kode.

Perbedaan latar belakang penutur bahasa dalam suatu komunitas memungkinkan terjadinya alih kode dan campur kode (Kurniasih dan Zuhriyah, 2017). a alih kode adalah suatu keadaan menggunakan satu bahasa atau lebih dengan memasukkan serpihan-serpihan atau unsur bahasa lain tanpa ada sesuatu yang menuntut pencampuran bahasa itu dan dilakukan dalam keadaan santai (Rulyandi, Rohmadi dan Sulistyo, 2014). campur kode adalah suatu keadaan menggunakan satu bahasa atau lebih dengan memasukkan serpihanserpihan atau unsur bahasa lain tanpa ada sesuatu yang menuntut pencampuran bahasa itu dan dilakukan dalam keadaan santai (Rulyandi, Rohmadi dan Sulistyo, 2014).

Penggunaan bahasa menimbulkan terjadinya peristiwa alih kode dan campur kode, dapat diketahui melalui komunikasi bahasa antar individu dengan latar belakang bahasa pertamanya. Campur Kode dan alih kode seringkali terjadi si suatu tempat yang di dalamnya terdapat berbagi etnis, suku, bahasa, dan ragam budaya (Akhii, Rahayu, dan Wulandari,2018). Dalam masyarakat bilingual atau multilingual, salah satunya masyarakat Cabangbungin peristiwa alih kode dan campur kode dalam komunikasi merupakan fenomena yang sering terjadi. Dikatakan demikian karena orang-orang yang terlibat dalam tindak komunikasi paling tidak menguasai lebih dari satu bahasa yang digunakan. Misalnya penutur menggunakan bahasa Nasional yaitu bahasa Indonesia dengan bahasa Regional, seperti bahwa Jawa Indramayu.

Wilayah Kecamatan Cabangbungin berada di daerah pelosok Kabupaten Bekasi, Jawa Barat. Kecamatan Cabangbungin dipilih sebagai tempat penelitian karena kecamatan tersebut merupakan salah satu wilayah yang masyarakatnya mempunyai bahasa yang menarik untuk diteliti. Cabangbungin bukan termasuk daerah dengan bahasa jawa sebagai bahasa ibu, tetapi terdapat beberapa desa yang memakai bahasa Jawa Indramayu sebagai bahasa sejak lahir. Masyarakat Cabangbungin termasuk daerah yang dominan berbahasa betawi seperti daerah Bekasi pada umumnya. Fenomena kebahasaan yang digunakan oleh masyarakat Cabangbungin, khususnya pada Desa Jayalaksana, Desa Setialaksana, dan Desa Sindangsari sangat menarik untuk dijadikan objek penelitian ini, karena bahasa komunikasi pada masyarakat di desa tersebut belum pernah ada yang meneliti objek tersebut menggunakan kajian sosiolinguistik. Oleh karena itu, penelitian ini dilakukan untuk mengulas lebih dalam dan terperinci bagaimana penggunaaan alih kode dan campur kode pada masyarakat Cabangbungin di Kabupaten Bekasi.

Penggunaan Alih Kode dan Campur Kode dalam Interaksi Masyarakat di Kecamatan Cabangbungin Kabupaten Bekasi 


\section{Lingua Rima: Jurnal Pendidikan Bahasa dan Sastra Indonesia \\ Vol. 10 No. 3 September 2021 \\ http://jurnal.umt.ac.id/index.php/lgrm}

Simatupang, Rohmadi dan Saddhono (2018) Judul Tuturan dalam Pembelajaran Bahasa Indonesia (Kajian Sosiolingustik Alih Kode dan Campur Kode). Penelitian ini bertujuan untuk mendeskripsikan faktor penyebab terjadinya alih kode dan campur kode dalam pembelajaran bahasa Indonesia yang digunakan oleh penutur di lingkungan SMK kota Medan. Metode yang digunakan ialah deskriptif kualitatif. Data dalam penelitian ini adalah bahasa - bahasa yang digunakan oleh guru dan siswa pada saat pembelajaran bahasa Indonesia. Pengumpulan data digunakan dengan teknik teknik pengamatan, teknik wawancara dan teknik rekam. Hasil penelitian menunjukkan bahwa Faktor-faktor penyebab Alih kode ialah (1) penutur, (2) lawan tutur, (3) hadirnya penutur ketiga, (4) pokok pembicaraan dan (5) membangkitkan rasa humor. Faktor penyebab campur kode ialah (1) ingin menjelaskan sesuatu, (2) karena situasi dan (3) ingin menjalin keakraban antara guru dan siswa

\section{B. METODE PENELITIAN}

Pada penelitian ini memakai pendekatan kualitatif, pendekatan kualitatif adalah pendekatan yang dilakukan secara utuh atau menyeluruh kepada subjek penelitian, di mana terdapat sebuah peristiwa bahwa peneliti yang menjadi instrumen atau kunci dalam penelitian. Hasil pendekatan diuraikan ke dalam bentuk kata-kata tertulis yang menjadi data empiris untuk diperoleh maknanya. Dalam pendekatan kualitatif peneliti menekankan pada subjek penelitian yaitu narasumber atau masyarakat Kecamatan Cabangbungin yang menggunakan alih kode dan campur kode dalam komunikasi sehari-hari. Metode yang digunakan dalam penelitian melalui tahap penyediaan data, digunakan metode cakap, yaitu berupa percakapan antara peneliti dengan penutur yang menjadi narasumbernya. Metode cakap dilakukan dengan bantuan teknik dasar, yaitu teknik pancing dan teknik lanjutan, yang terdiri atas tiga teknik yaitu teknik cakap semuka, teknik rekam, dan teknik catat.

Subjek penelitian ini adalah beberapa masyarakat Kecamatan Cabangbungin, di sini peneliti memakai 3 narasumber yaitu: Anisah (18) dari Desa Jayalaksana, Umi (17) dari Desa Setialaksana, dan Nela (18) dari Desa Sindangsari. Mereka bertiga adalah masyarakat Cabangbungin dari 3 desa berbeda. Peneliti mengambil objek dari tindak tutur masyarakat Kecamatan Cabangbungin, peneliti mereduksi cara penggunaan alih kode dan campur kode bahasa Jawa Indramayu pada masyarakat Cabangbungin di kehidupan sehari-hari. Penelitian ini memakai teknik pengumpulan data melalui terjun langsung ke lapangan atau observasi. Peneliti memakai teknik cakap, rekam, dan catat. Setelah mendapatkan data melalui teknik Penggunaan Alih Kode dan Campur Kode dalam Interaksi Masyarakat di Kecamatan Cabangbungin Kabupaten Bekasi 
cakap, rekam, dan catat, maka peneliti mengolah data tersebut menjadi sebuah transkripsi dan dijabarkan bagaimana wujud penggunaan alih kode dan campur kode pada masyarakat Cabangungin. Teknik analisis data dalam penelitian ini dengan cara klasifikasi data, dan analisis data. Pada penelitian alih kode dan campur kode data diidentifikasi berdasarkan hasil rekaman dalam bentuk transkrip yang berupa tulisan untuk menentukan atau menganalisis wujud alih kode dalam komunikasi sehari-hari masyarakat Kecamatan Cabangbungin, Kabupaten Bekasi. Teknik analisis ini dilakukan sesudah pengumpulan data, dengan memperoleh data tuturan pada masyarakat Kecamatan Cabangbungin, Kabupaten Bekasi. Cara menemukan wujud alih kode dan campur kode berdasarkan hasil transkripsi perekaman audio yang sudah dilakukan proses klasifikasi.

\section{HASIL PENELITIAN DAN PEMBAHASAN}

Kecamatan Cabangungin memiliki 8 Desa, diantaranya: Desa Lenggahjaya, Desa Setiajaya, Desa Lenggahsari, Desa Sindangjaya, Desa Sindangsari, Desa Jayabakti, Desa Setialaksana, dan Deasa Jayalaksana. Seluruhnya terdapat delapan desa tersebut, tiga diantaranya memakai bahasa Jawa Indramayu sebagai bahasa ibu atau bahasa lahir. Hal itu disebabkan pada zaman dahulu banyaknya perantau dari daerah Indramayu dan Cirebon yang menetap dan menikah dengan masyarakat Desa Setialaksana, Desa Sindangsari, dan Desa Jayalaksana. Bahasa Jawa Indramayu menjadi bahasa keseharian, namun beranjaknya zaman masyarakat desa tersebut lebih sering mencampurkan dengan bahasa Indonesia betawi. Data yang dihasilkan dari penelitian ini dengan cara memahami dan menerjemahkan bahasa yang digunakan dalam interaksi pada masyarakat Kecamatan Cabangbungin, Kabupaten Bekasi.

Peneliti melakukan olah data yang menjadi tujuan untuk mendapatkan pemahaman dari percakapan yang dituturkan, data ini diperoleh untuk dianalisis wujud alih kode dan campur kode dalam interaksi masyrakat Kecamatan Cabangbungin. Jumlah alih kode ditemukan sebanyak 4 alih kode secara keseluruhan dan keempatnya alih kode internal. Sedangkah jumlah campur kode ditemukan sebanyak 6 campur kode secara keseluruhan. Campur kode internal sebanyak 2 campur kode, dan campur kode eksternal sebanyak 4 campur kode. 
Tabel 4.1 Hasil Penelitian Alih Kode dan Campur Kode Masyarakat Kecamatan Cabangbungin Kabupaten Bekasi

\begin{tabular}{|c|c|c|c|c|}
\hline \multirow{2}{*}{ No. } & \multirow{2}{*}{ Data Tuturan } & \multicolumn{3}{|c|}{$\begin{array}{c}\text { Gejala } \\
\text { Bahasa }\end{array}$} \\
\hline & & $\begin{array}{c}\text { Alih } \\
\text { Kode }\end{array}$ & $\begin{array}{c}\text { Campur } \\
\text { Kode }\end{array}$ & Keterangan \\
\hline 1. & $\begin{array}{l}\text { Anisah: Alis buatin noh, pake pantat } \\
\text { dandang. (Alis buat tuh, pakai alas } \\
\text { dandang) } \\
\text { Umi: Dikerok ya, luh kira pantat dandang } \\
\text { masih zaman dikerok- kerok (Digosok } \\
\text { ya, kamu kira alas dandang masih } \\
\text { zaman digosok-gosok) } \\
\text { Nela: Tapi emang ana ya, sing geneng } \\
\text { mokonon beneran ana ya? (Tetapi } \\
\text { memang ada ya, yang suka begitu } \\
\text { beneran ada ya?) } \\
\text { Anisah: Ana, ari zaman baheula. Emak- } \\
\text { emak geneng } \\
\text { mengkonon, alise dikerok pake pantat } \\
\text { dandang. (Ada, kalau zaman dahulu. } \\
\text { Ibu-ibu suka begitu, alisnya digosok } \\
\text { pakai } \\
\text { alas dandang) }\end{array}$ & $\checkmark$ & & $\begin{array}{l}\text { Alih kode tesebut } \\
\text { berupa alih bahasa } \\
\text { yang meliputi } \\
\text { peralihan bahasa } \\
\text { Betawi ke dalam } \\
\text { bahasa } \\
\text { Indramayu. }\end{array}$ \\
\hline 2. & $\begin{array}{l}\text { Umi: Iku si Nela kun, ning ngarepe (Itu si } \\
\qquad \text { Nela, di depan) } \\
\text { Anisah: Kita iku ya, arep metu ge iku }\end{array}$ & $\checkmark$ & & $\begin{array}{l}\text { Alih kode tesebut } \\
\text { berupa } \\
\text { alih bahasa yang } \\
\text { meliputi peralihan } \\
\text { dari bahasa }\end{array}$ \\
\hline
\end{tabular}


Lingua Rima: Jurnal Pendidikan Bahasa dan Sastra Indonesia

Vol. 10 No. 3 September 2021

http://jurnal.umt.ac.id/index.php/lgrm

\begin{tabular}{|c|c|c|c|}
\hline & $\begin{array}{l}\text { Nel ya wedi. Wedi ada serigala } \\
\text { berkeliaran. (Aku itu ya, mau } \\
\text { keluar Nel tapi takut, takut ada } \\
\text { serigala berkeliaran) } \\
\text { Umi: Iya, gua mah keluar takut eh, } \\
\text { takut darah suci gua diambil. } \\
\text { Kan gua anuh, sapah tuh ya } \\
\text { namanya gua, Nayla wkwk (Iya, } \\
\text { aku mah keluar takut, takut } \\
\text { darah suci aku diambil. Kan } \\
\text { aku, siapa itu ya namanya?, } \\
\text { Nayla wkwk) } \\
\text { Anisah: Kata gua, iya ya ini tensi gua } \\
\text { (Kata aku, iya ya ini tensi aku) } \\
\text { Nela: Pas di tensi, darahe kita 90, kan } \\
\text { gua kurang ya, ini habis malam } \\
\text { purnama hahaha (Waktu } \\
\text { ditensi, darahnya aku 90, kan } \\
\text { aku kurang ya, ini habis malam } \\
\text { purnama hahaha) }\end{array}$ & & $\begin{array}{l}\text { Jawa Indramayu ke dalam } \\
\text { bahasa betawi. }\end{array}$ \\
\hline 3. & $\begin{aligned} \text { Anisah: } & \text { Soale wedine kapasitase } \\
& \text { terlalu full kan, terlalu full } \\
& \text { ning batre ikane, batere hpne. } \\
& \text { (Soalnya takutnya kapasitas } \\
& \text { baterainya terlalu penuh kan, } \\
& \text { terlalu penuh baterai ininya, } \\
& \text { baterai handphone-nya) }\end{aligned}$ & $\checkmark$ & $\begin{array}{l}\text { Campur kode yang } \\
\text { berwujud kata bahasa } \\
\text { Jawa Indramayu ke bahasa } \\
\text { asing. Campur kode yang } \\
\text { terdapat pada tuturan itu } \\
\text { termasuk campur kode } \\
\text { ekstern. }\end{array}$ \\
\hline
\end{tabular}




\begin{tabular}{|c|c|c|c|c|}
\hline 4. & $\begin{aligned} \text { Anisah: } & \text { Iya, wedi hpne terlalu full } \\
& \text { kan, terlalu full dadi baterene } \\
& \text { rusak, apasih cepet lobet ya. } \\
& \text { (Iya, takut handphone-nya } \\
& \text { terlalu penuh kan, terlalu } \\
& \text { penuh jadi baterainya cepat } \\
& \text { low batt [baterai lemah]) }\end{aligned}$ & & $\checkmark$ & $\begin{array}{l}\text { Campur kode yang } \\
\text { berwujud kata bahasa } \\
\text { Jawa Indramayu ke bahasa } \\
\text { Asing. Campur kode pada } \\
\text { tuturan itu termasuk } \\
\text { campur kode ekstern. }\end{array}$ \\
\hline 5. & $\begin{array}{rrr}\text { Anisah: } & \text { Jangan dicas aja } & \text { hpnya } \\
& \text { (Jangan dicas } & \text { aja } \\
& \text { handphone-nya) } & \text { Ari } \\
& \text { misalkan turuku ya, aja di cas } \\
& \text { hpne. (Kalau misalnya tidur } \\
& \text { tuh ya, jangan dicas hpnya) }\end{array}$ & $\checkmark$ & & $\begin{array}{l}\text { Alih kode yang terjadi } \\
\text { pada tuturan Anisah } \\
\text { adalah alih kode intern, hal } \\
\text { ini menunjukan adanya } \\
\text { peralihan dari bahasa } \\
\text { Indonesia ke bahasa Jawa } \\
\text { Indramayu atau satu kode } \\
\text { ke kode bahasa lain. }\end{array}$ \\
\hline 6. & $\begin{array}{l}\text { Anisah: Terlalu absurd hidupnya, } \\
\text { (Terlalu tidak masuk akal } \\
\text { hidupnya) } \\
\text { Umi: Dicoba Nel, (Dicoba, Nel.) } \\
\text { Nela: Ora ah, ira ge kenapa? (Tidak, } \\
\text { kamu saja kenapa?) } \\
\text { Umi: Iki perute warek (Ini perutnya } \\
\text { kenyang) } \\
\text { Nela: Warek, aduh yaya, yaya } \\
\text { (Kenyang, aduh sakit, sakit) }\end{array}$ & $\checkmark$ & & $\begin{array}{l}\text { Alih kode yang terjadi } \\
\text { dalam percakapan Anisah, } \\
\text { Umi, dan Nela. Adanya } \\
\text { peralihan dari bahasa } \\
\text { Indonesia ke bahasa Jawa } \\
\text { Indramayu Nela yang } \\
\text { berpindah kode ke bahasa } \\
\text { Jawa Indramayu sehingga } \\
\text { Umi menanggapi } \\
\text { menggunakan bahasa } \\
\text { yang sama. }\end{array}$ \\
\hline
\end{tabular}


Lingua Rima: Jurnal Pendidikan Bahasa dan Sastra Indonesia

Vol. 10 No. 3 September 2021

http://jurnal.umt.ac.id/index.php/lgrm

\begin{tabular}{|c|c|c|c|}
\hline 7. & $\begin{array}{l}\text { Umi: Kalo gue yang ngomong "aduh } \\
\text { yaya" gak pantes pisan luh, nela } \\
\text { lebih ceta banget kalongomong } \\
\text { yaya. (Kalau aku ngomong } \\
\text { "aduh sakit" gak pantas banget, } \\
\text { Nela lebih fasih kalau } \\
\text { ngomong.) }\end{array}$ & $\checkmark$ & $\begin{array}{l}\text { Campur kode yang } \\
\text { berwujud kata bahasa } \\
\text { Jawa Indramayu dan } \\
\text { bahasa betawi ke bahasa } \\
\text { Indonesia, campur kode } \\
\text { ini disebut campur kode } \\
\text { intern. Adanya campuran } \\
\text { kode dalam tuturan } \\
\text { tersebut. }\end{array}$ \\
\hline 8. & $\begin{array}{r}\text { Umi: Tadinya mau gua papin ke luh, } \\
\text { takut luhnya gak percaya kalo } \\
\text { itu blood moon (Sebelumnya } \\
\text { mau aku kirim foto ke kamu, }\end{array}$ & $\checkmark$ & $\begin{array}{l}\text { Campur kode yang } \\
\text { berwujud bahasa asing, } \\
\text { campur kode ini disebut } \\
\text { campur kode ekstern, }\end{array}$ \\
\hline & $\begin{array}{l}\text { takut kamu gak percaya kalau } \\
\text { itu gerhana bulan darah) }\end{array}$ & & $\begin{array}{l}\text { yaitu adanya sebutan } \\
\text { bahasa asing di dalam } \\
\text { tuturan bahasa Indonesia. }\end{array}$ \\
\hline 9. & $\begin{array}{l}\text { Umi: Nis, nis luh mau ngeliat bulan } \\
\text { gak? (Nis, Nis kamu mau lihat } \\
\text { bulan tidak?) } \\
\text { Anisah: Gua mah kan Nel, kita mah } \\
\text { kan beneran ya ngomong } \\
\text { emang kita ora metu, ora } \\
\text { metu kita ge. (Aku mah kan } \\
\text { ya Nel, aku mah beneran ya } \\
\text { ngomongnya, aku tidak } \\
\text { keluar, tidak keluar akumah) }\end{array}$ & $\checkmark$ & $\begin{array}{l}\text { Campur kode yang } \\
\text { berwujud bahasa Jawa } \\
\text { Indramayu dalam tuturan } \\
\text { Anisah, campur kode ini } \\
\text { disebut campur kode } \\
\text { intern, yaitu adanya } \\
\text { campuran kode dari } \\
\text { bahasa Indonesia ke } \\
\text { bahasa Jawa Indramayu. }\end{array}$ \\
\hline
\end{tabular}

Penggunaan Alih Kode dan Campur Kode dalam Interaksi Masyarakat di Kecamatan Cabangbungin Kabupaten Bekasi 


\begin{tabular}{|c|c|c|c|}
\hline 10. & $\begin{array}{l}\text { Nela: Ahire iku chatingan ning loro? } \\
\text { (Akhirnya kamu chattingan } \\
\text { berdua dia?) } \\
\text { Anisah: Iya, ngeselaken de batur gitu, } \\
\text { mana pas banget lagi typing } \\
\text { ya. Ora kita keluarin iku } \\
\text { saking ku penasaran ya Nel, } \\
\text { ora tak keluari masih di pesan. } \\
\text { Pas iku dibuka, mana kena } \\
\text { wifi langsung kebuka kan. } \\
\text { Umi anjay. Astaghfirullah. } \\
\text { Yang keluar serigala. (Iya, } \\
\text { ngeselin temen begitu, di } \\
\text { mana pas banget lagi menulis } \\
\text { ya. Tidak aku keluarkan itu, } \\
\text { karena penasaran ya Nel, tidak } \\
\text { aku keluarin masih di dalam } \\
\text { pesan. Pas itu dibuka, mana } \\
\text { pakai wifi, langsung kebuka } \\
\text { kan, Anjay, } \\
\text { Astaugfirullah) }\end{array}$ & $\checkmark$ & $\begin{array}{l}\text { Campur kode ekstern yang } \\
\text { terdapat pada kata tuturan } \\
\text { Anisah,kata chatting, } \\
\text { typing, wifi, dan } \\
\text { astaghfirullah yang } \\
\text { berasal dari bahasa Asing } \\
\text { dicampur ke dalam bahasa } \\
\text { Jawa Indramayu. }\end{array}$ \\
\hline
\end{tabular}

\section{Aspek Alih Kode}

Pada hasil percakapan yang sudah dianalisis peneliti menemukan 4 wujud alih kode yang keempatnya adalah alih kode internal, dalam sebuah percakapan antara Anisah, Umi, dan Nela. Mereka adalah seorang warga di Kecamatan Cabangbungin, Kabupaten Bekasi. Dalam percakapan mereka menggunakan beberapa bahasa dalam tuturannya, yaitu bahasa Jawa Indramayu, bahasa Indonesia, dan bahasa betawi.

Pada bagian percakapan di bawah ini ditemukan alih kode internal antarbahasa sehingga terjadinya peralihan dari bahasa betawi ke bahasa Jawa Indramayu. Penggalan percakapan dilakukan oleh tiga orang narasumber, dalam percakapan tersebut mereka membicarakan tentang pada zaman dahulu masyarakat membuat alis memakai alas 
dandang. Pada bagian percakapan terdapat dua kode bahasa yang berbeda, yakni bahasa betawi dan bahasa Jawa Indramayu. Percakapan awalnya dilakukan oleh Anisah dan Nela menggunakan bahasa betawi, kemudian adanya peralihan bahasa menjadi bahasa Jawa Indramayu sebab masuknya Nela ke dalam percakapan menggunakan bahasa Jawa Indramayu, sehingga Anisah menanggapi tuturan Nela menggunakan bahasa Jawa Indramayu. Berikut ini penggalan percakapan wujud alih kode internal, yaitu:

Anisah : Alis buatin noh, pake pantat dandang. (Alis buat tuh, pakai alas dandang) Umi : Dikerok ya, luh kira pantat dandang masih zaman dikerok-kerok (Digosok ya, kamu kira alas dandang masih zaman digosok-gosok)

Nela : Tapi pancen ana ya, sing geneng mokonon beneran ana ya? (Tetapi memang ada ya, yang suka begitu beneran ada ya?)

Anisah : Ana, ari zaman baheula. Emak-emak geneng mengkonon, alise dikerok pake pantat dandang. (Ada, kalau zaman dahulu. Ibu-ibu suka begitu, alisnya digosok pakai alas dandang).

Penggalan lain kebalikan dari percakapan di atas, adanya peralihan bahasa Jawa Indramayu ke bahasa betawi, percakapan awalnya dilakukan oleh Umi yang memberi tahu Anisah bahwa Nela di depan rumahnya pada saat malam gerhana bulan menggunakan bahasa Jawa Indramayu. Kemudian Anisah mengatakan bahwa dia tak ingin keluar rumah, Umi pun menanggapi memakai bahasa betawi bahwa mereka tidak keluar karena takut, lalu lanjutan percakapan mengalami peralihan bahawa menjadi bahasa betawi. Berikut ini penggalam peralihan bahasa Jawa Indramayu ke bahasa betawi, yaitu:

Umi : Iku si Nela kun, ning ngarepe (Itu si Nela, di depan)

Anisah : Kita iku ya, arep metu ge iku Nel ya wedi. Wedi ada serigala berkeliaran. (Aku itu ya, mau keluar Nel tapi takut, takut ada serigala berkeliaran)

Umi : Iya, gua mah keluar takut eh, takut darah suci gua diambil. Kan gua anuh, sapah tuh ya namanya gua, Nayla wkwk (Iya, aku mah keluar takut, takut darah suci aku diambil. Kan aku, siapa itu ya namanya?, Nayla wkwk)

Anisah : Kata gua, iya ya ini tensi gua (Kata aku, iya ya ini tensi aku)

Nela : Pas ditensi, darahe kita 90, kan gua kurang ya, ini habis malam purnama hahaha (Waktu ditensi, darahnya aku 90, kan aku kurang ya, ini habis malam purnama hahaha)

Dalam alih kode internal ini penutur menggunakan bahasa Indonesia kemudian beralih ke bahasa Jawa Indramayu. Suasana yang terjadi dalam tuturan ini adalah Anisah yang memberi tahu kepada mitra tuturnya untuk tidak mengisi baterai handphone pada saat tertidur. Berikut penggalan dari tuturan Anisah, yaitu: 


\section{Lingua Rima: Jurnal Pendidikan Bahasa dan Sastra Indonesia \\ Vol. 10 No. 3 September 2021 \\ http://jurnal.umt.ac.id/index.php/lgrm}

Anisah: Jangan dicas aja hpnya (jangan dicas aja handphone-nya ) Ari misalkan turuku ya, aja di cas hpne (kalau misalnya tidur tuh ya, jangan dicas hpnya)

Penggalan lainnya terdapat pada percakapan yang dilakukan oleh Anisah, Umi, dan Nela. Adanya peralihan bahasa karena pihak ketiga mengganti topik pembicaraan yang awalnya membahas kehidupan absurd zaman dahulu kemudian berpindah ketika Nela menolak, dan bertanya kepada Umi. Berikut ini penggalan percakapan, yaitu:

Anisah : Terlalu absurd hidupnya, (Terlalu tidak masuk akal hidupnya) Umi : Dicoba Nel, (dicoba, Nel.)

Nela : Ora ah, ira ge kenapa? (Gak, kamu aja

kenapa?) Umi : Iki perute warek (Ini perutnya

kenyang)

Nela : Warek, aduh yaya, yaya (Kenyang, aduh sakit, sakit)

\section{Wujud Campur Kode}

a. Campur kode internal

Campur kode yang berwujud kata bahasa Jawa Indramayu dan bahasa betawi ke bahasa Indonesia. Adanya campuran kode dalam tuturan tersebut, sebagaimana penggalan tuturan berikut ini:

Umi: Kalo gue yang ngomong "aduh yaya" gak pantes pisan luh, nela lebih ceta banget kalo ngomong yaya. (kalau aku ngomong "aduh sakit" gak pantas banget, Nela lebih fasih kalau ngomong.)

Kata yaya yang mempunyai arti sakit diucap ulang oleh Umi yang kurang fasih dalam berbahasa Jawa Indramayu, sehingga cara bicaranya kurang enak didengar. Kemudian kata ceta yang dalam bahasa Indonesia dapat diartikan sebagai kata fasoh atau lancar. Dalam penyipisan unsur-unsur berwujud frasa terdapat pada penggalan percakapan berikut ini:

Umi : Nis, nis luh mau ngeliat bulan gak? (Nis, Nis kamu mau lihat bulan tidak?) Anisah : Gua mah kan Nel, kita mah kan beneran ya ngomong emang kita ora metu, ora metu kita ge. (Aku mah kan ya Nel, aku mah beneran ya ngomongnya, aku tidak keluar, tidak keluar aku mah)

Frasa ora metu, ora metu kita ge diucapkan ditengah tuturan bahasa Indonesia, sehingga terjadinya campur kode dalam bahasa Jawa Indramayu.

\section{b. Campur Kode Eksternal}

Campur kode yang berwujud bahasa asing, campur kode ini disebut campur kode ekstern, yaitu adanya sebutan bahasa asing di dalam tuturan bahasa Indonesia. Berikut ini penggalan dari wujud campur kode eksternal, yaitu: 
Lingua Rima: Jurnal Pendidikan Bahasa dan Sastra Indonesia

Vol. 10 No. 3 September 2021

http://jurnal.umt.ac.id/index.php/lgrm

Anisah : Soale wedine kapasitase terlalu full kan, terlalu full ning batre ikane, batere hpne. (Soalnya takutnya kapasitas baterainya terlalu penuh kan, terlalu penuh baterai ininya, baterai handphone-nya)

Anisah : Iya, wedi hpne terlalu full kan, terlalu full dadi baterene rusak, apasih cepet lobet ya. (Iya, takut handphone-nya terlalu penuh kan, terlalu penuh jadi baterainya cepat low batt [baterai lemah])

Pada tuturan yang diucapkan oleh Anisah terdapat dua bahasa asing yaitu kata full dan lobet, kata tersebut terdengar familiar di telinga masyarakat. Namun, yang harus diketahui bahwa kata tersebut adalah bahasa asing yang berarti 'penuh' dan 'baterai lemah.'

Umi : Tadinya mau gua papin ke luh, takut luhnya gak percaya kalo itu blood moon (tadinya mau aku kirim foto ke kamu, takut kamu gak percaya kalau itu gerhana bulan darah)

Kemudian pada tuturan Umi terdapat kata dari bahasa asing yaitu blood moon yang berarti bulan darah, yang memang pada saat itu belum lama terjadinya gerhana bulan darah.

Nela : Ahire iku chatingan ning loro? (Akhirnya kamu chattingan berdua dia?)

Anisah : Iya, ngeselaken de batur gitu, mana pas banget lagi typing ya. Ora kita keluarin iku saking ku penasaran ya Nel, ora tak keluari masih di pesan. Pas iku dibuka, mana kena wifi langsung kebuka kan. Umi anjay. Astaghfirullah. Yang keluar serigala. (Iya, ngeselin temen begitu, di mana pas banget lagi menulis ya. Tidak aku keluarkan itu, karena penasaran ya Nel, tidak aku keluarin masih di dalam pesan. Pas itu dibuka, mana pakai wifi, langsung kebuka kan, Umi Anjay, Astaghfirullah.)

Pada tuturan Nela terdapat kata dari bahasa asing yaitu Chatting yang berarti mengobrol, kata chatting lebih terdengar familiar dibanding menyebutkan kata mengobrol. Selanjutnya pada tuturan yang disampaikan oleh Anisah terdapat tiga kata dari bahasa asing yaitu typing, wifi, dan astaghfirullah. Typing merupakan kata dari bahasa asing yang berarti menulis, Anisah memakai kata typing mungking karena peraturan handphonenya memakai bahasa Inggris. Sedangkan kata wifi yang merupakan kepanjangan dari wireless fidelity yaitu teknologi jaringan tanpa kabel, masyarakat sekitar biasa menyebut kata wifi sebagai jaringan nirkabel untuk internet. Kata astaghfirullah merupakan serapan dari bahasa Arab, Anisah mengucap astaghfirullah sebagai ungkapan kekesalan atas kejahilan Umi.

\section{SIMPULAN DAN SARAN}

Berdasarkan hasil penelitian dan pembahasan mengenai alih kode dan campur kode 
pada interaksi masyarakat Kecamatan Cabangbungin, Kebupaten Bekasi yang dikaitkan dengan rumusan masalah dan tujuan penelitian disampaikan menjadi beberapa bagian, yaitu alih kode dalam interaksi masyarakat Kecamatan Cabangbungin, Kabupaten Bekasi ditemukan 4 alih kode berwujud alih kode internal. Campur kode dalam interaksi masyarakat Kecamatan Cabangbungin, Kabupaten Bekasi ditemukan 6 campur kode, yang diantaran 2 campur kode internal dan 4 campur kode eksternal. Bagi peneliti lain yang mungkin saja tertarik dengan bidang kajian yang sama, dapat melakukan kajian dengan data dan sumber data lain agar hasil penelitian lebih beragam danbervariasi, serta dapat memberikan lebih banyak ilmu penegtahuan dalam penelitian alih kode dan campur kode.

\section{E. DAFTAR PUSTAKA}

Akhii, L., Rahayu, N., dan Wulandari, C. 2018. Campur Kode dan Alih Kode dalam Percakapan di Lingkup Perpustakaan Universitas Bengkulu.Jurnal Ilmiah Korpus. Vol 2 No 1 Hal 45-55

Kurniasih, D. Dan Zuhriyah, S. A. 2017. Alih Kode dan Campur Kode di Pondok Pesantren Mahasiswa Darussalam. Journal Indonesian Language Education and Literature. Vol 3 No 1 Hal 53-65

Rulyadi, Rohmadi, M., dan Sulistyo, E. T. 2014. Alih Kode dan Campur Kode dalam Pembelajaran Bahasa Indonesia di SMA. Jurnal Pedagogia. Vol 17 No 1 Hal 27-39

Simatupang, R. R., Rohmadi, M., dan Saddhono, K. 2018. Tuturan dalam Pembelajaran Bahasa Indonesia (Kajian Sosiolinguistik Alih Kode dan Campur Kode). Jurnal Kajian Linguistik dan Sastra. Vol 3 No 2 Hal 119-130 